\title{
Effect of Different Soilless Substrates on Flowering, Yield and Fruit Quality of Strawberry (Fragaria $x$ ananassa Duch.) cv. Chandler under Protected Conditions
}

\author{
Mamta Thakur ${ }^{1}$ and Bunty Shylla ${ }^{2 *}$ \\ ${ }^{1}$ Department of Fruit Science, Dr. Y S Parmar University of Horticulture and Forestry, \\ Nauni-173230, Solan, HP, India \\ ${ }^{2}$ Horticulture Research and Training Station and KVK, Kandaghat, HP, India \\ *Corresponding author
}

\section{A B S T R A C T}

\begin{tabular}{|c|}
\hline Keywords \\
\hline $\begin{array}{l}\text { Growing media, Perlite + } \\
\text { FYM, Strawberry, Yield, } \\
\text { Fruit quality }\end{array}$ \\
\hline Article Info \\
\hline $\begin{array}{l}\text { Accepted: } \\
23 \text { March } 2018 \\
\text { Available Online: } \\
10 \text { April } 2018\end{array}$ \\
\hline
\end{tabular}

\section{Introduction}

Strawberry (Fragaria x ananassa Duchesne) is a member of the Rosaceae family and has resulted from a cross between two wild strawberries: Fragaria virginiana (Meadow strawberry) and Fragaria chiloensis (Chilean strawberry).

Among all soft berries like brambles, strawberry and currants, strawberries are the most favourite soft berry fruits of the temperate world. It is an herbaceous perennial runner adaptable to wide range of agroclimatic conditions from subtropics to temperate climate (Singh et al., 2006). Strawberry is highly remunerative fruit and gives high returns per unit area in a short time. The fruit are in great demand for fresh market as well as in processing industry. In India, it is grown commercially in the states of Maharashtra, Punjab, Haryana, Karnataka, Madhya Pradesh, Jammu \& Kashmir, Himachal Pradesh and Uttarakhand. The most commonly grown cultivar in the country, Chandler, is a short day high yielding variety bearing quality fruits. Strawberry cultivation is mainly restricted to open field conditions. Growing strawberry in open conditions however results in fruits with poor size and 
quality. On the other hand, cultivation of strawberry under protective conditions yields more with better quality fruits.

Non-availability of good and healthy planting material is the limiting factor in commercial strawberry cultivation as soil borne pathogens, nematodes and the soil conditions play a negative role in the production of healthy elite planting material. Soil-borne pathogens are often associated with severe production losses in strawberry culture. To eliminate soil borne diseases and pests, the use of soilless growing media is therefore of utmost importance and is gaining popularity. A wide variety of soilless media are currently in use in different parts of the world to act as suitable substitutes for soil (De-Rijck and Schrevens, 1998). Out of these growing media, the most commonly used soilless growing media for strawberries are peat moss, rockwool, perlite and cocopeat.

The properties of the constituents of different growing media are known to have direct and indirect effects on plant growth and productivity. Among all properties of growing media, pore space, water holding capacity, bulk density, $\mathrm{pH}$, soluble salt content and distribution of the particles size are important physical and chemical properties.

\section{Materials and Methods}

The present investigation was carried out at the Horticultural Research and Training Station and Krishi Vigyan Kendra (HRTS \& KVK) Kandaghat, Solan in Himachal Pradesh during the cropping seasons of 2015-16 and 2016-17 using Completely Randomized Block Design (CRBD) for statistical analysis of the results obtained during the course of studies. The experiment had six treatments, each with four replications consisting 24 beds $(1 \times 1 \mathrm{~m})$ in which strawberry cultivar 'Chandler' runners were planted at a spacing of 20x $20 \mathrm{~cm}$ during October, 2015 and 2016.
The beds were lined with black polythene sheet upto twelve inches and subsequently filled with different soilless substrates according to the treatments $\left(\mathrm{T}_{1}-\mathrm{T}_{6}\right)$. The plants were irrigated at 1-2 days interval through microsprinkler irrigation during the initial stages and later by using drip irrigation during fruiting stage while recommended dose of fertilizers were applied through fertigation using soluble fertilizers (19:19:19). All plants were subjected to uniform cultural practices during the course of investigations. Ten plants per treatment were randomly marked for recording the observations. The effects of soilless substrates were observed on flowering, yield and fruit quality parameters were recorded as per standard practices. The floral characteristics were recorded during the flowering season. The percent berry set/ plant was calculated by using the formula given by Westwood (1993). The weight of entire fruits harvested per plant was recorded for each treatment and yield per plant was worked out accordingly. The fruit size and weight of ten randomly selected berries was determined and average was worked out. The quality parameters like total soluble solids were determined with the help of a hand refractrometer. The titratable acidity and sugar contents were determined by volumetric methods given by AOAC (1980). The data recorded over a period of two years was pooled and statistically analyzed with the standard procedure as suggested by Panse and Sukhatme by using MS-Excel and OPSTAT (Sheoran et al., 1998). The level of significance for different variables was tested at 5 percent level of significance.

\section{Results and Discussion}

The data presented in Table 1 clearly indicates that different treatments of soilless substrates had significant effect on flowering and fruiting parameters of strawberry. A perusal of the pooled data reveals that the maximum number 
of flowers (16.07) was recorded in plants grown under perlite $+\mathrm{FYM}\left(\mathrm{T}_{2}\right)$ treatment which was statistically superior to all other treatments and minimum number of flowers (13.61) was recorded under soil + FYM $\left(\mathrm{T}_{6}\right)$ treatment treatment. Similarly, the maximum per cent berry set $(81.34 \%)$ was recorded in plants grown under $\mathrm{T}_{2}$ treatment which was however statistically at par with perlite $\left(\mathrm{T}_{1}\right)$ treatment and minimum berry set $(71.83 \%)$ was obtained in $\mathrm{T}_{2}$ treatment.

These results are in accordance with the findings of Anagnostou et al., (1995) who have also observed early flower production in strawberry cv. Fern and Selva when plants were raised in soilless substrate perlite under greenhouse condition. Better flowering and berry set in artificial media compared to the soil may have resulted due to the improvement in root zone environment.

Nourizadeh (2003) also observed that the number of flowers in plants increased due to favourable conditions in soilless substrate resulting from good ventilation and regular availability of water. The results obtained under present studies are however in contrast to the findings of Joshi (2003) who failed to get significant effect of soilless media on number of days to first flower and duration of flowering.

It is apparent from the data presented in Table 1 that the treatments comprising of various soilless substrates were found to significantly different in respect of berry yield per plant. The pooled data reveals that the highest berry yield of $203.32 \mathrm{~g}$ per plant was observed under perlite $+\mathrm{FYM}\left(\mathrm{T}_{2}\right)$ treatment closely followed by perlite $\left(\mathrm{T}_{1}\right)$ treatment. However, minimum berry yield per plant $(185.11 \mathrm{~g})$ was recorded under soil + FYM $\left(\mathrm{T}_{6}\right)$ treatment. The positive influence of perlite and its mixtures on better root development could be the reason behind improved aeration resulting in better root system which in turn might have promoted shoot nutrient uptake leading to increased berry yield. Similar results of increased yield in perlite and its mixtures have been reported in strawberry cv. Sweet Charlie (Cantliffe et al., 2008) and Camarosa strawberry (Hochmuth, 2008).

The data also indicates that the berry length was maximum $(38.01 \mathrm{~mm})$ in plants grown under perlite $+\mathrm{FYM}\left(\mathrm{T}_{2}\right)$ treatment though it was statistically at par with perlite $\left(\mathrm{T}_{1}\right)$ alone, whereas the least berry length $(33.08 \mathrm{~mm})$ was obtained under soil+ FYM $\left(\mathrm{T}_{6}\right)$ treatment. The largest berry breadth of $25.55 \mathrm{~mm}$ was recorded under perlite + FYM $\left(\mathrm{T}_{2}\right)$ treatment whereas the smallest berry breadth $(21.57$ $\mathrm{mm})$ was recorded under soil $+\mathrm{FYM}\left(\mathrm{T}_{6}\right)$ treatment. These results are in accordance with the findings of Fornes et al., (2003) and Ayesha et al., (2011) who found perlite mixed with manure increased the berry size in strawberry and the increase in size was attributed to the ability of this medium to provide essential micro nutrients to the plants.

The pooled data set out in Table 2 indicates that all the treatments of growing media had a significant effect on berry weight in comparison to the control treatment $\left(\mathrm{T}_{6}\right)$. The maximumt berry weight $(21.62 \mathrm{~g})$ was recorded in plants that were grown under perlite + FYM $\left(\mathrm{T}_{2}\right)$ treatment which was found to be statistically at par with perlite $\left(\mathrm{T}_{1}\right)$ whereas the minimum berry weight (17.45 g) was recorded under soil + FYM treatment $\left(\mathrm{T}_{6}\right)$. These results are in congruence with the findings of Linardakis and Manios (1991) who also recorded highest fruit in plants grown in case of strawberry cv. Selva grown on Peat + Perlite medium. Similar results were also reported by Paraskevopoulou et al., (1995) who obtained maximum yield and berry weight in Selva cultivar of strawberry when grown in soilless mixture as compared to normal soil solution. 
Table.1 Effect of different growing media on flowering, yield and berry size in strawberry cv. Chandler

\begin{tabular}{|c|c|c|c|c|c|}
\hline Treatment & $\begin{array}{l}\text { Number of } \\
\text { flowers }\end{array}$ & $\begin{array}{l}\text { Per cent } \\
\text { berry set } \\
\quad(\%)\end{array}$ & $\begin{array}{c}\text { Berry } \\
\text { yield per } \\
\text { plant (g) }\end{array}$ & $\begin{array}{c}\text { Berry } \\
\text { length } \\
(\mathrm{mm})\end{array}$ & $\begin{array}{c}\text { Berry } \\
\text { breadth } \\
\text { (mm) }\end{array}$ \\
\hline & Pooled & Pooled & Pooled & Pooled & Pooled \\
\hline $\mathrm{T}_{1}$ Perlite & 15.16 & $\begin{array}{c}81.11 \\
(64.22)\end{array}$ & 201.39 & 37.51 & 24.79 \\
\hline $\mathrm{T}_{2}$ Perlite + FYM (1:1) & 16.07 & $\begin{array}{c}81.34 \\
(64.38)\end{array}$ & 203.32 & 38.01 & 25.55 \\
\hline $\mathrm{T}_{3}$ Cocopeat & 14.86 & $\begin{array}{c}75.26 \\
(60.15)\end{array}$ & 189.14 & 33.38 & 22.78 \\
\hline $\mathrm{T}_{4}$ Cocopeat + FYM (1:1) & 14.98 & $\begin{array}{c}76.48 \\
(60.97)\end{array}$ & 190.52 & 34.00 & 23.64 \\
\hline $\begin{array}{l}\text { T5 Perlite + Cocopeat + } \\
\text { FYM }(1: 1: 1)\end{array}$ & 15.09 & $\begin{array}{c}79.84 \\
(63.30)\end{array}$ & 196.64 & 36.04 & 23.88 \\
\hline $\mathrm{T}_{6}$ Soil + FYM (1:1) & 13.61 & $\begin{array}{l}71.83 \\
(57.92)\end{array}$ & 185.11 & 31.53 & 21.57 \\
\hline $\mathrm{CD}_{(0.05)}$ & 0.33 & 0.50 & 0.79 & 1.40 & 0.57 \\
\hline
\end{tabular}

Table.2 Effect of different growing media on berry weight and quality in strawberry cv. Chandler

\begin{tabular}{|l|c|c|c|c|c|c|}
\hline \multicolumn{1}{|c|}{ Treatments } & $\begin{array}{c}\text { Berry } \\
\text { weight } \\
(\mathbf{g})\end{array}$ & $\begin{array}{c}\text { Total } \\
\text { soluble } \\
\text { solids } \\
(\%)\end{array}$ & $\begin{array}{c}\text { Titratable } \\
\text { acidity } \\
(\%)\end{array}$ & $\begin{array}{c}\text { Total } \\
\text { sugars } \\
(\%)\end{array}$ & $\begin{array}{c}\text { Reducing } \\
\text { sugars } \\
(\%)\end{array}$ & $\begin{array}{c}\text { Non- } \\
\text { reducing } \\
\text { sugars }(\%)\end{array}$ \\
\hline$T_{1}$ Perlite & Pooled & Pooled & Pooled & Pooled & Pooled & Pooled \\
\hline$T_{2}$ Perlite + FYM (1:1) & 21.21 & 10.09 & 0.80 & 7.37 & 5.34 & 1.93 \\
\hline$T_{3}$ Cocopeat & 21.62 & 10.52 & 0.78 & 7.49 & 5.38 & 1.99 \\
\hline$T_{4}$ Cocopeat + FYM (1:1) & 18.52 & 9.37 & 0.83 & 6.98 & 5.23 & 1.66 \\
\hline$T_{5}$ Perlite + Cocopeat + FYM (1:1:1) & 18.93 & 9.49 & 0.84 & 7.16 & 5.26 & 1.80 \\
\hline$T_{6}$ Soil + FYM & 20.47 & 9.82 & 0.83 & 7.30 & 5.32 & 1.88 \\
\hline CD $_{0.05}$ & 17.45 & 8.50 & 0.85 & 6.74 & 4.95 & 1.71 \\
\hline
\end{tabular}

\section{Treatments}

\begin{tabular}{|l|l|}
\hline $\mathrm{T}_{1:}$ & Perlite \\
\hline $\mathrm{T}_{2:}$ & Perlite + FYM $(1: 1)$ \\
\hline $\mathrm{T}_{3}:$ & Cocopeat \\
\hline $\mathrm{T}_{4:}$ & Cocopeat + FYM $(1: 1)$ \\
\hline $\mathrm{T}_{5:}$ & Perlite + Cocopeat + FYM $(1: 1: 1)$ \\
\hline $\mathrm{T}_{6}:$ & Soil+ FYM (Control) \\
\hline
\end{tabular}


It was observed under the present studies that Perlite + FYM $\left(\mathrm{T}_{2}\right)$ treatment significantly increased total soluble solids and reduced the titratable acidity in fruits. Perlite $\left(\mathrm{T}_{1}\right)$ treatment was also found to increase the total soluble solids in fruits. It is apparent from the data given in Table 2 that the total soluble solids of the berries in the present studies were the highest $\left(10.52^{\circ} \mathrm{B}\right)$ uner perlite + FYM $\left(\mathrm{T}_{2}\right)$ treatment followed by perlite $\left(\mathrm{T}_{1}\right)$ treatment. The lowest total soluble solid contents of $8.50^{\circ} \mathrm{B}$ were recorded in the berries of the plants raised in soil + FYM $\left(\mathrm{T}_{6}\right)$ treatment. The positive effect of perlite and its mixtures on total soluble solids could be attributed to improved nutrient availability due to better features of the growing media. These findings are in conformity with that of Ghazvani et al., (2007) who recorded the highest total soluble solids in mixture of perlite medium than perlite alone. Similarly, Jafarnia et al., (2010) reported significantly higher percentage of total soluble solids when plants were grown in mixture of perlite.

Different soilless substrates had only a slight difference in their effects on titratable acidity of fruits of strawberry cv. Chandler. However, soil + FYM $\left(\mathrm{T}_{6}\right)$ treatment recorded the highest titratable acidity ( 0.85 per cent) while perlite + FYM $\left(\mathrm{T}_{2}\right)$ treatment recorded the lowest titratable acidity ( 0.79 per cent $)$ though it was statistically at par with perlite $\left(\mathrm{T}_{1}\right)$ treatment. The present results showed that titratable acidity was higher in control treatment than all other treatments. This could be attributed to lesser breakdown of metabolites in fruits. Similar results were reported by Sharma (2015) who ascribed the higher acidity content in strawberries grown in soil to the longer period required by these fruit to reach harvesting stage as compared to those grown in soilless growing media which on the contrary matured and ripened earlier. These results are also in line with the findings of Davis (1964) and Hassan et al., (2011) who reported higher acidic fruits when grown in soil and lower acidic fruits when grown in other media like coconut coir. Contrary to this, Fernandez et al., (2006) did not find any significant difference as far as values of acidity in fruits are concerned when grown with or without soil.

The results under present study revealed that the treatment perlite + FYM $\left(\mathrm{T}_{2}\right)$ significantly increased the sugar content (Table 2). Plants grown under $\mathrm{T}_{2}$ treatment resulted in significant increase in total sugars content and reducing sugars content over control as the maximum total sugars content (7.49\%), reducing sugars $(5.38 \%)$ and non-reducing sugars $(1.99 \%)$ was recorded in perlite + FYM $\left(\mathrm{T}_{2}\right)$ followed by perlite $\left(\mathrm{T}_{1}\right)$. The significant differences observed in various combinations of soilless media during the present studies with respect to sugars might be due to the different proportion of growing substrates which may have changed the physical and chemical properties of the substrates thereby significantly influencing the quality characteristics in strawberry fruits. The results are also in line with the findings of Jafarnia et al., (2010), Inden and Torres (2004) and Ameri et al., (2012), who reported the positive influence of various combinations of substrate on sugar content. The increase in sugars could also be due to the acceleration of growth and fruiting and possible physiological processes like synthesis of carbohydrates in plant system (Key 1969), thereby, increasing the sugars content in berries. These results are in conformity with the findings of various research workers who studied the performance of strawberry while using perlite as a growing media (Paraskevopoulou et al., 1990 and Vassilakakis et al., 1991).

On the basis of the results obtained in present investigation, it is inferred that $\mathrm{t}$ perlite + FYM soilless substrate significantly increased 
the flowering, berry set, berry size, weight and berry yield of strawberry over other treatments including control. Perlite treatment was found to have positive effect on improvement of fruit size, yield and fruit quality and resulted in significant increase in berry yield and weight over control. It can thus be concluded that perlite in combination with FYM is very effective and can be successfully used for the production of good quality strawberry under polyhouse.

\section{References}

Ameri A, Tehranifar A, Ameri GH, Tehranifar AA, Davarynejad GH and Shoor M. 2012. The effects of substrate and cultivar in quality of strawberry. Journal of Biodiversity and Environmental Sciences 6: 181- 188.

Anagnostou K, Vasilakakis MD, Gerasopoulos D, Olympios C and Passam H. 1995. Effect of substrate and cultivar on earliness, plant productivity and fruit quality of strawberry. Acta Horticulturae 379:267-274.

AOAC. 1980. Official Methods of Analysis. Association of Official Analytical Chemists. Washington DC, USA. 33: 617-623.

Ayesha R, Fatima N, Ruqayya M, Faheem H, Qureshi KM, Hafiz IA, Khan KS, Ali U and Kamal A. 2011. Influence of different growth media on the fruit quality and reproductive growth parameters of strawberry (Fragaria $\times$ ananassa Duch.). Journal of Medicinal Plants Research 5: 6224-6232.

Cantliffe DJ, Castellanos JZ and Paranjpe AV. 2008. Yield and quality of greenhouse grown strawberries as affected by nitrogen level in coco coir and pine bark media. In: Proceedings of the Florida State Horticultural Society 120: 157-161.
Davis JN. 1964. Effect of nitrogen, phosphorous and potassium fertilizers on the non-volatile organic acids of tomato fruit. Journal of the Science of Food Agriculture 15:665-673.

De-Rijck G and Schrevens E. 1998. Distribution of nutrients and water in rockwool slabs. Scientia Horticulturae 72: 277-285.

Fernandez MA, Hernanz D, Toscano G, Hernandez MC, Peralbo A, Flores F and Lopez-Medina J. 2006. Strawberry quality in soilless systems. Acta Horticulturae 708: 409-412.

Fornes F, Belda RM, Abad M, Noguera P, Puchades R, Maquieira A and Noguera V. 2003. The microstructure of coconut coir dusts for use as alternatives to peat in soilless growing media. Australian Journal of Experimental Agriculture 43: 1171-1179.

Ghazvani RF, Payvast $G$ and Azarian $H$. 2007. Effect of growing media on growth and yield of strawberry. International Journal of Agriculture and Biology 9: 885-888.

Hassan AH, Khereba AH, El-Kattan MH, Noha G and El- Rahman A. 2011. Effect of various organic substrate culture and container types on productivity and fruit quality of strawberry (Fragaria $\times$ ananassa) cv. Festival. Research Journal of Agriculture and Biological Sciences 7: 379-387.

Hochmuth G. 2008. Containerized strawberry transplants reduce establishment period water use and enhance growth and flowering compared with bare-root plants. HortTechnology 16: 46-54.

Inden $\mathrm{H}$ and Torres A. 2004. Comparison of four substrates on the growth and quality of

Jafarnia S, Khosrowshahi S, Hatamzadeh A and Tehranifar A. 2010. Effect of substrate and variety on some important 
quality and quantity characteristics of strawberry production in vertical hydroponics system. Advances in Environmental Biology 4: 360-363.

Joshi PS. 2003. Effect of growing media, bioregulators and nutrients on growth, yield and quality of strawberry $c v$. Chandler. PhD Thesis. Department of Fruit Science, Dr YS Parmar

Key JL. 1969. Hormone and nucleic acid metabolism. Annual Review of Plant Physiology 20: 449-474.

Linardakis DK and Manios BI. 1991. Hydroponic culture of strawberries in plastic greenhouse in a vertical system. Acta Horticulturae 287: 317-326.

Nourizadeh M. 2003. The effect of different substrate cultivation on the growth, performance and to evaluate the cold acclimation and freezing quality of greenhouse cucumber in without soil cultivation system. M.Sc. Thesis. Horticulture, Guilan University, Iran.

Panse VG and Sukhatme PV. 2000. Statistical Methods for Agricultural Workers. Indian Council of Agricultural Research, New Delhi, India. pp. 157165.

Paraskevopoulou G, Grefiadellis M, Paroussis E, Maloupa E and Gerasopoulos D. 1995. Precocity, plant productivity and fruit quality of strawberry plants grown in soil and soilless culture. Acta Horticulturae 408: 109-117.
Paraskevopoulou G, Vassilakakis $\mathrm{M}$ and Dogras C. 1990. Performance of five strawberry cultivars under plastic greenhouse on field conditions in Northern Greece. Acta Horticulturae 287: 273-279.

Sharma VK. 2015. Effect of soilless growing substrates on vegetative growth and roots of strawberry cv. Sweet Charlie. The Ecoscan 9:89-91.

Sheoran OP, Toonk DS, Kaushik LS, Hasija RC and Pannu RS. 1988. Statistical software package for agricultural research workers. In: Recent Advances in Information Theory, Statistics and Computer Application (Hooda DS and Hasija RC eds). Department of mathematical statistics, CCS HAU, Hisar. pp. 139-143.

Singh A and Singh JN. 2006. Studies on influence of bio-fertilizers and bioregulators on flowering, yield and fruit quality of strawberry cv. Sweet Charlie. Annals of Agricultural Research 27:261-264.

Vassilakakis M, Dogras C, Vlachonasios C and Mastrokostas. 1991. Out of season strawberry production under glasshouse condition. $15^{\text {th }}$ Annual meeting of Greek Society for Horticulture Sciences pp. 12-14.

Westwood MN. 1979. Temperate Zone Pomology. WH Freeman and Company San Francisco. 282p.

\section{How to cite this article:}

Mamta Thakur and Bunty Shylla. 2018. Effect of Different Soilless Substrates on Flowering, Yield and Fruit Quality of Strawberry (Fragaria $x$ ananassa Duch.) cv. Chandler under Protected Conditions. Int.J.Curr.Microbiol.App.Sci. 7(04): 2830-2836.

doi: https://doi.org/10.20546/ijcmas.2018.704.322 